\title{
Analisis Teknis dan Ekonomis Konversi Barge Batubara Menjadi Kapal Pengangkut Ikan Hidup untuk Perairan Sumbawa
}

\author{
I Made Candra Astanugraha, dan Hasanudin \\ Departemen Teknik Perkapalan, Fakultas Teknologi Kelautan, Institut Teknologi Sepuluh Nopember \\ (ITS) \\ e-mail: hasanudin@na.its.ac.id
}

\begin{abstract}
Abstrak-Menurunya harga dan tingkat ekspor terhadap tambang pada komoditi batubara, yang disebabkan oleh krisis ekonomi yang melanda Eropa dan pengalihan sumber energi ke sumber energi substitusi semacam energi matahari menyebabkan industri pengiriman yang salama ini banyak memanfaatkan barge juga mengalami penurunan, tercatat $60 \%$ barge yang tidak beroperasi akibat menurunya industri batubara, yang tentunya sangat tidak sehat untuk industri dibidang perkapalan, mengingat biaya pemangunan untuk satu barge dapat mencapai milliaran rupiah. Melihat kondisi ini tentunya diperlukan langkah yang mampu mengembalikan keadaan yang dimana sebelumnya banyak barge yang tidak beroperasi kembali dapat beroperasi. Salah satu cara tepat ialah dengan mengubah fungsi barge itu, yang awalnya mengangkut batubara menjadi pengangkut ikan hidup, hal ini tepat mengingat pemerintah sedang gencarnya meningkatkan dan meratakan produksi ikan di Indonesia, dan melalui Peraturan Pemerintah Kementrian Kelautan dan Perikanan No. 15 Tahun 2016, diperlukan penambahan armada untuk pengangkut ikan hidup, tentunya hal ini dapat mengembalikan pemanfaatan dari barge di Indonesia. Tujuan dari penelitian ini ialah memperoleh desain konversi barge menjadi self-propelled barge pengangkut ikan hidup yang dapat memenuhi owner requirement sesuai produksi ikan di Sumbawa, desain yang dapat memenuhi kriteria teknis dan penghitungan biaya ekonomisnya, dilakukan dengan menghitung kelayakan investasi kapal, dimana untuk biaya awal investasi kapal ini sebesar Rp15,936,542,123, dan periode kembalinya diperoleh dalam waktu 5 tahun.
\end{abstract}

Kata Kunci-Self Proppeled Barge, Ikan, Ikan Hidup, Analisi Teknis Dan Ekonomi, Konversi.

\section{PENDAHULUAN}

$\mathrm{B}$ $A R G E$ merupakan perahu agak besar (untuk mengangkut barang dan sebagainya) (KBBI, 2015). barge adalah suatu jenis kapal dengan lambung datar atau suatu kotak besar yang mengapung, digunakan untuk mengangkut barang dan ditarik dengan kapal tunda (tugboat). Barge sendiri tidak memiliki sistem pendorong (propulsi) seperti kapal pada umumnya.Pada umumnya, barge digunakan untuk mengangkut muatan dalam jumlah besar seperti kayu, batubara, pasir, dan lain-lain [1].

Belakangan ini seiring dengan penurunan harga dari batubara dan penurunan permintaan ekspor dari luar menyebabkan banyak barge yang tidak beoperasi secara optimal, tercatat kurang lebih $60 \%$ barge yang sudah tidak beroperasi, kejadian ini membuat banyak barge yang berakhir pada mesin scrap, hal ini tentunya sangat disayangkan karena merugikan secara finansial mengingat biaya produksi untuku satu kapal barge bisa mencapai angka Rp. 24 Milyar.

Sehubungan dengan hal tersebut disisi lain pemerintah sedang gencarnya meningkatkan produksi ikan nasional melalui berbagi cara guna meningkatkan kesejahteraan hidup masyarakat pesisir, beberapa langkah pemerintah antara lain membangun 3.450 kapal nelayan baru yang sedang dilaksanakan, serta yang terbaru ialah terbitnya peraturan pemerintah no 15 tahun 2016 mengenai kapal pengangkut ikan hidup, tujuan dari terbitnya peraturan pemerintah ini ialah untuk memenuhi kebutuhan armada dari kapal pengangkut ikan hidup di Indonesia, yang sebelumnya dianggap kurang memenuhi kebutuhan akan armada kapal pengangkut ikan hidup, dimana jumlah sebelumnya diangap belum mampu mengakomodir jumlah ikan hidup, sehingga banyak dari hasil tangkapan yang tidak terakomodir.

Oleh karena hal tersebut penulis beranggapan perlu diadakan konversi kapal dari barge menjadi kapal pengangkut ikan hidup, sehingga kapal-kapal yang tidak beroperasi dengan maksimal tidak memberi dampak kerugian secara finansial dan juga secara tidak langsung meningkatkan produksi ikan nasional sesui dengan rencana strategis pemerintah.

\section{TINJAUAN PUSTAKA}

\section{A. Perairan Sumbawa}

Perairan Sumbawa khususnya Selat Alas merupakan daerah perairan yang termasuk kedalam daerah teritorial kabupaten Sumbawa Barat, Nusa Tenggara Barat. Dikenal sebagai daerah dengan potensi ikan yang cukup besar, nama selat alas sempat menjadi sentra penangkapan cumi-cumi terbesar NTB dengan kontribusi tangkapan sebesar $7 \%$ dari produksi Nasional, selain memproduksi jenis ikan cumi-cumi, terdapat beberpa tangkapan ikan lainya yang menjadi tangkapan utama diperairan selat alas diantaranya kerapu, kakap, tenggiri, gurita, selar dan lainya. Secara geografis selat alas berada diantara kabupaten Lombok Timur dan kabupaten Sumbawa Barat. Letak dari Selat Alas dapat dilihat pada Gambar 1 yang diperoleh dari jurnal Pengelolaan Perikanan Tangkap Berbasis 
Ikan Unggulan do Selat Alas Provinsi Nusa Tenggara Barat [2].

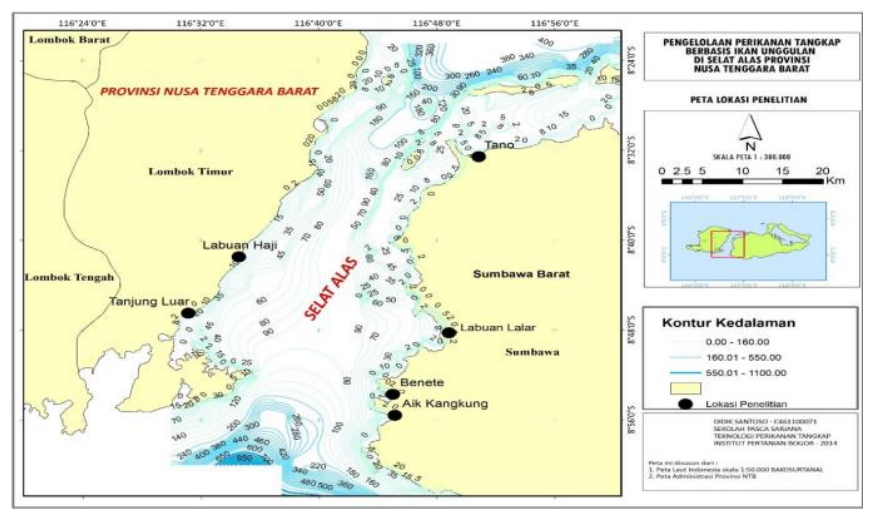

Gambar 1. Perairan Sumbawa (Selat Alas).

\section{B. Barge dan Self Barge sebagai Alat Angkut}

Barge adalah kapal dengan lambung datar, baik memiliki sistem penggerak ataupun tidak, yang digunakan untuk mengangkut muatan di kanal ataupun sungai. Contoh muatan yang biasa diangkut oleh barge adalah pasir ataupun batubara, tergantung kebutuhan. Barge adalah salah satu variant dari kapal kontainer yang sudah diisi muatan sebelumnya [3]. Self Propelled Barge (SPB) dapat diartikan sebegai kapal yang berbentuk menyerupai barge, namun menggunakan sistem pendorong sendiri (tanpa dibantu oleh tug boat). Apabila dibandingkan dengan biaya pembangunan kapal pada umumnya terlbebih kapal bulk carrier, SPB mempunyai biaya pembangunan yang lebih rendah $1 / 3$ kali dari kapal bulk carrier [4].

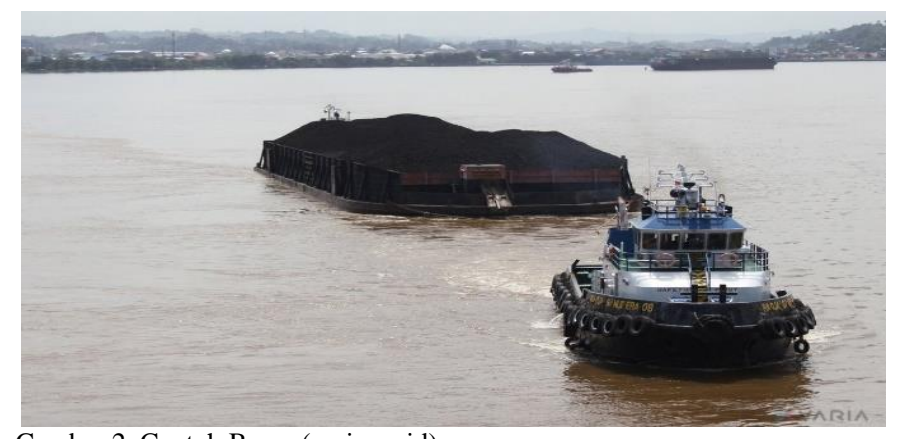

Gambar 2. Contoh Barge (varia.co.id)

\section{Konversi Kapal}

Dalam Pengerjaan Konversi diperlukan data-data penunjang berupa, lines plan kapal, general arrangement kapal yang akan dikonversi, langkah awalnya ialah dengan melakukan redraw dan permodelan dari lambung kapal, pada software maxsurf modeler, nantinya adapun acuan peraturan yang digunakan selama proses konversi ialah BKI, SOLAS, IMO, dll.

\section{ANALISIS TEKNIS}

Sebelum mulai dilakukakan modifikasi harus didapatkan terlebih dahulu data barge Kim Heng. Barge Kim Heng merupakan kapal yang dimiliki oleh P.T. Mitratirta Lokalestari, yang digunakan untuk mengangkut hasil tambang batubara, didaerah. Data barge Kim Heng yang didapatkan dari PT. Mitratirta Lokalestari berupa principal dimensions, Lines Plan, General Arrangement, dan Construction Profil.

Setelah data tersebut didapatkan sebagai langkah awal bisa dilakukan pemodelan lambung barge Kim Heng. Untuk langkah selanjutnya dapat dilakukan modifikasi kapal dan analisis teknis lainnya.

Berikut merupakan data awal barge Kim Heng yang akan dikonversi menjadi self propelled barge pengangkut ikan hidup.
1. Nama Kapal
Bendera Kebangsaan
: Kim Heng Barge
Klasifikasi
: Indonesia
Galangan Pembuat
: Biro Klasifikasi Indonesia (BKI)
Tipe Kapal
: PT. Mitratirta Lokalestari
2. Ukuran Utama
Panjang Seluruh (LOA) : 54.9 meter
Lebar
Tinggi
Draft
$: 15.25$ meter
: 3.05 meter
: 2.1 meter
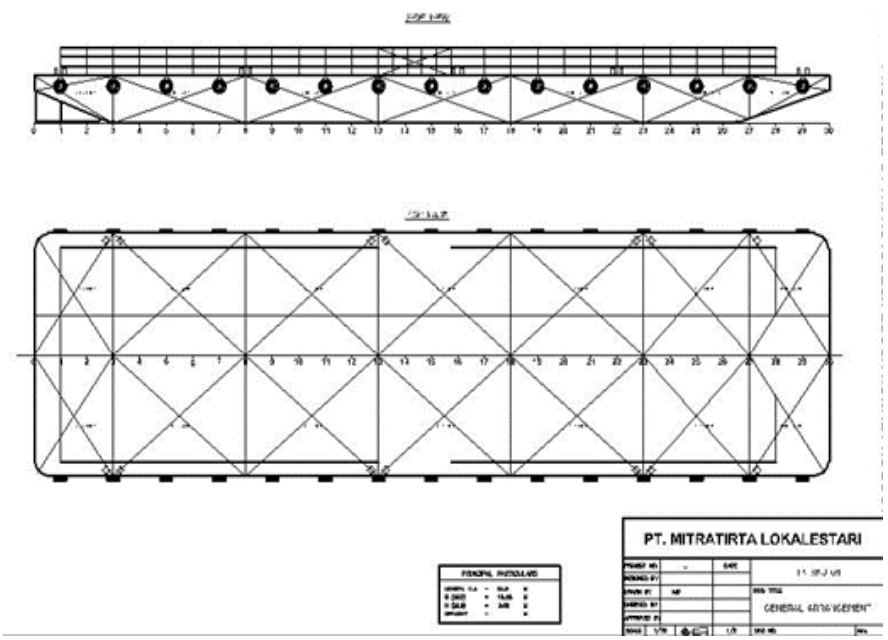

Gambar 3. General Arrangement Barge Kim Heng

\section{A. Penentuan Payload}

Dari tahap pengumpulan data produksi dan data potensi maksimum produksi ikan di perairan Sumbawa diperoleh 12 jenis ikan yang merupakan produksi utama untuk perairan Sumbawa, dimana penentuan 12 jenis ikan ini didasarkan pada jumlah tangkapan tahunan dan potensi lestari maksimum ikan tersebut.

Berdasarkan Tabel diambil rata-rata setiap 15 harinya dimana diperoleh 256.876 ton/15hari, lalu dikalikan dengan jumlah perbandingan ikan dan air sebanya $70 \%$ air dan $30 \%$ ikan, maka massa total diperoleh sebesar 856.25 ton.Jumlah masa total inilah yang digunakan sebagai payload dari kapal ini.

$$
\begin{array}{ll}
\text { Payload } & =\mathrm{a} \times \mathrm{b} \times \text { rasio } \\
\mathrm{a} & =\text { total tangkapan dalam } 1 \text { hari } \\
\mathrm{b} & =\text { perkiraan trip } 15 \text { hari sekali } \\
\text { payload } & =(17.125 \text { ton } \mathrm{x} 15 \text { hari }) / 0.3 \\
& =856.25 \text { ton } / 15 \text { hari }
\end{array}
$$


Dengan perbandingan rasio ikan dan air tadi kita mencari masa jenis gabungan ikan dan air:

$$
\begin{array}{ll}
\text { Rasio ikan } & =30 \% \times 856.25 \times 0.98=254.32 \mathrm{~m}^{3} \\
\text { Rasio air } & =70 \% \times 856.25 \times 1.025=614.18 \mathrm{~m}^{3} \\
\text { Jumlah } & =868.412 \mathrm{~m} 3
\end{array}
$$

Massa jenis gabungan = payload/total volume

$$
\begin{aligned}
& =856.25 / 868.412 \\
& =0.98 \mathrm{~m} 3 / \mathrm{ton}
\end{aligned}
$$

Lalu untuk menentukan volume minimal untuk ruang

\begin{tabular}{|c|c|c|c|}
\hline \multicolumn{4}{|c|}{ Produksi Ikan Rata-Rata } \\
\hline ikan kerapu & $=$ & 259.1 & ton/tahun \\
\hline ikan kakap & $=$ & 317.8 & ton/tahun \\
\hline ikan tembang & $=$ & 306.5 & ton/tahun \\
\hline gurita & $=$ & 245 & ton/tahun \\
\hline ikan tenggiri & $=$ & 103.8 & ton/tahun \\
\hline ikan tongkol & $=$ & 1493 & ton/tahun \\
\hline cumi & $=$ & 657.2 & ton/tahun \\
\hline ikan kuwe & $=$ & 158.1 & ton/tahun \\
\hline ikan kembung & $=$ & 319.3 & ton/tahun \\
\hline ikan lemuru & $=$ & 574 & ton/tahun \\
\hline ikan selar & $=$ & 152.6 & ton/tahun \\
\hline ikan cakalang & $=$ & 1493 & ton/tahun \\
\hline total & $=$ & 6079.4 & ton/tahun \\
\hline rata-rata dalam 1 hari & $=$ & 17.12507042 & ton/hari \\
\hline rata-rata dalam 30 hari & $=$ & 256.8760563 & ton \\
\hline \multicolumn{4}{|c|}{ massa total air dan ikan } \\
\hline rata-rata dalam 30 hari & $=$ & 256.8760563 & ton \\
\hline rasio air & $=$ & $70 \%$ & \\
\hline rasio ikan & $=$ & $30 \%$ & \\
\hline massa total air dan ikan & $=$ & 0 & ton \\
\hline massa jenis gabungan & $=$ & 0.98 & ton $/ \mathrm{m}^{3}$ \\
\hline Volume ruang muat & $=$ & 941.9 & $\mathrm{~m}^{3}$ \\
\hline
\end{tabular}
penyimpanan yang diperlukan ialah dengan 856.25 ton/0.98 $\mathrm{m} 3 /$ ton diperoleh $941.6 \mathrm{~m}^{3}$.

$$
\text { Tabel } 1 .
$$

Jenis Ikan Yang Diangkut

\section{B. Perhitungan Berat Kapal}

Setelah kapal dikonversi perlu dilakukan perhitungan untuk mendapatkan principal dimensions kapal setelah dilakukan konversi. Berat kapal total terdiri dari berat komponenkomponen DWT dan LWT. Pada Tabel 2 dapat dilihat berat kapal total (displacement) yang terdiri dari komponen berat DWT dan LWT adalah 1524.27 ton.

Tabel 2.

Rekapitulasi Berat Kapal Total

\begin{tabular}{ccc}
\multicolumn{3}{c}{ Rekapitulasi Berat Kapal Total } \\
\hline \hline No & Item & Weight (ton) \\
\hline 1 & Displacement (Design) & 1585.87 \\
& Displacement \\
1 & Light Weight Tonnage \\
2 & Berat Baja Kapal & 336.92 \\
3 & Berat E\&O & 131.27 \\
& Berat Instalasi Permesinan & 162.15 \\
1 & Dead Weight Tonnage \\
2 & Payload & 856.23 \\
3 & Berat Bahan Bakar & 4.92 \\
\hline \hline
\end{tabular}

\begin{tabular}{ccc}
\hline \hline 4 & Berat Air Tawar & 5.36 \\
5 & Berat Provision & 0.05 \\
6 & Berat Orang dan Bawaan & 1.33 \\
& LWT + DWT & 1524.47 \\
& Displacement (Design) & 1585.87 \\
& Margin & $61.4(3.87 \%)$ \\
\hline
\end{tabular}

\section{Perhitungan Titik Berat kapal}

Titik berat kapal dihitung dari persebaran berat semua komponen berat disepanjang kapal. Untuk mendapatkan nilai persebaran berat lambung harus dilakukan persebaran berat DWT, berat mesin beserta perlengkapan, bangunan atas, dan peralatan serta perlengkapan terlebih dulu. Dari rekapitulasi persebaran berat kapal total dapat dihitung titik berat kapal total (LCG) dengan perhitungan berikut :

Titik berat kapal diperoleh dari titik berat LWT dan DWT.

$$
\begin{array}{ccc}
\text { Titik berat LWT } & \text { Tititk berat DWT } \\
\text { KG }=2.6 \mathrm{~m} & \text { KG }=3.4 \mathrm{~m}
\end{array}
$$$$
\text { LCG }(F P)=28.80 \mathrm{~m} \quad \text { LCG }(F P)=28.89 \mathrm{~m}
$$

Titik berat total kapal KG $=3.14 \mathrm{~m}, \mathrm{LCG}$ dari $\mathrm{FP}=-27.901$ m. LCG kapal ialah -27.901 m dari FP, Sedangkan KG kapal ialah $3.14 \mathrm{~m}$.

\section{Perhitungan Freeboard}

Pemeriksaan freeboard atau lambung timbul mengacu pada ketentuan International Convention on Load Lines (ICLL) 1966, IMO (International Maritime Organization)[5]. Pemeriksaan kondisi lambung timbul dilakukan pada kondisi kapal sebelum maupun sesudah dilakukan konversi.

Tabel 3.

Hasil Pemeriksaan Freeboard

\begin{tabular}{cccc}
\hline \multicolumn{4}{c}{ Rekapitulasi Freeboard } \\
\hline No & Item & Result & Unit \\
2 & Tipe Kapal & Tipe A & \\
& Freeboard Standard & 512 & $\mathrm{~mm}$ \\
Koreksi-Koreksi & & \\
& Koreksi kapal ukuran < 100 m & 0.00 & $\mathrm{~mm}$ \\
Koreksi Cb & 101.88 & $\mathrm{~mm}$ \\
Koreksi Tinggi & 0.00 & $\mathrm{~mm}$ \\
& Koreksi Bangunan Atas & -35.82 & $\mathrm{~mm}$ \\
Koreksi Sheer & 23.79 & $\mathrm{~mm}$ \\
& Koreksi minimum bow height & 0.00 & $\mathrm{~mm}$ \\
& Freeboard Total & 601.56 & $\mathrm{~mm}$ \\
& Actual Freeboard & 950.00 & $\mathrm{~mm}$ \\
& Remark & OK & \\
\hline \hline
\end{tabular}

\section{E. Perhitungan Ruang Muat}

Merupakan perhitungan volume semua ruangan yang terletak di bawah geladak kapal ditambah dengan volume ruangan tertutup yang terletak di atas geladak ditambah dengan isi ruangan beserta semua ruangan tertutup yang terletak di atas geladak paling atas (superstructure). Hal hal yang diperhitungkan dalam perencanaan ruang muat ini antara lain, dimensi ruang muat kapal, perencanaan tangki, perencanaan struktur dasar kapal.

Gross Tonnage (GT) merupakan ukuran volume ruangan kapal yang tertutup secara keseluruhan (total enclosed space), mulai dari ruangan kapal di bawah geladak cuaca $\left(\mathrm{V}_{\mathrm{U}}\right)$ sampai 
ruangan bangunan atas kapal $\left(\mathrm{V}_{\mathrm{H}}\right)$. Dan hasil perhitungan adalah sebagai berikut :

$\begin{array}{ll}\text { Gross Tonnage } & =\mathrm{V} * \mathrm{~K} 1 \\ \text { Total Enclosed Space } & =3123.396 \mathrm{~m} 3 \\ \mathrm{~K} 1 & =0.270 \quad ; 0,2+0,02 * \log 10(\mathrm{~V}) \\ \text { Gross Tonnage } & =843\end{array}$

\section{F. Pemeriksaan Kondisi Keseimbangan Kapal}

Kriteria kondisi pemuatan (loadcase) yang digunakan pada perhitungan ini mengacu pada Intact Stability (IS) Code Ch. III/3.5. SPB Kim Heng merupakan tipe kapal yang mengangkut kendaraan beserta muatannya dan penumpang. Sehingga kondisi pemuatannya sama dengan kapal penumpang barang. Kondisi pemuatan untuk kapal penumpang barang adalah sebagai berikut :

- Loadcase 1 : Kondisi ketika tangki muatan penuh (98\%), dan tangki bahan bakar penuh (100\%)

- Loadcase 2 : Kondisi ketika tangki muatan penuh (98\%), dan tangki bahan bakar tidak penuh (50\%)

- Loadcase 3: Kondisi ketika tangki muatan penuh (98\%), dan tanhki bahan bakar tidak penuh (10\%)

-Loadcase 4 : Kondisi ketika tangki muatan tidak penuh (78\%), dan tangki bahan bakar penuh (100\%)

-Loadcase 5 : Kondisi ketika tangki muatan tidak penuh (78\%), dan tangki bahan bakar tidak penuh (50\%)

-Loadcase 6 : Kondisi ketika tangki muatan tidak penuh (78\%), dan tangki bahan bakar tidak penuh (10\%)

- Loadcase 7 : Kondisi ketika tangki muatan kosong (0\%), dan tangki bahan bakar penuh (100\%)

- Loadcase 8 : Kondisi ketika tangki muatan kosong (0\%), dan tangki bahan bakar tidak penuh (50\%)

- Loadcase 9 : Kondisi ketika tangki muatan kosong (0\%), dan tangki bahan bakar tidak penuh (10\%)

\section{1) Pemeriksaan Kondisi Stabilitas}

Salah satu kreteria yang harus dipenihi dalam proses desain kapal ialah kriteria stabilitas. Analisis stabilitas digunakan untuk mengetahui keseimbangan kapal secara melintang atau oleng pada beberapa kriteria kondisi pemuatan (loadcase). Kriteria stabilitas yang digunakan adalah kriteria stabilitas untuk kapal jenis umum dan kapal penumpang yang mengacu pada Intact Stability (IS) Code Reg. III/3.1.2. Dalam perhitungan stabilitas ini digunakan software maxsurf stability untuk mengukur hasil dari kesesuain dari setiap kriteria stabilitas[6].

Tabel 4.

Rekapitulasi Stabilitas Kapal

\begin{tabular}{ccccccc}
\hline \hline Data & $\begin{array}{c}\mathrm{e}_{0-30^{\circ}} \\
(\mathrm{m} . \mathrm{deg})\end{array}$ & $\begin{array}{c}\mathrm{e}_{0-40^{\circ}} \\
(\mathrm{m} . \mathrm{deg})\end{array}$ & $\begin{array}{c}\mathrm{e}_{30-40^{\circ}} \\
(\mathrm{m} . \mathrm{deg})\end{array}$ & $\begin{array}{c}\mathrm{h}_{30^{\circ}} \\
(\mathrm{m} . \mathrm{deg})\end{array}$ & $\begin{array}{c}\theta_{\max } \\
(\mathrm{deg})\end{array}$ & $\begin{array}{c}\mathrm{GM}_{0} \\
(\mathrm{~m})\end{array}$ \\
\hline 1 & 29.5157 & 43.689 & 14.1724 & 1.452 & 28.8 & 6.972 \\
2 & 29.5257 & 43.7193 & 14.1936 & 1.453 & 28.8 & 6.897 \\
3 & 29.6769 & 43.9381 & 14.2612 & 1.46 & 28.8 & 6.891 \\
4 & 30.4414 & 44.1222 & 13.6807 & 1.415 & 28.2 & 6.742 \\
5 & 30.3967 & 44.0672 & 13.6705 & 1.413 & 28.2 & 6.687 \\
6 & 30.5262 & 44.2462 & 13.7200 & 1.418 & 28.2 & 6.703 \\
7 & 63.8818 & 93.9874 & 30.1056 & 3.065 & 28.8 & 10.886 \\
\hline \hline
\end{tabular}

\begin{tabular}{ccccccc}
\hline \hline 8 & 63.8885 & 94.0082 & 30.1197 & 3.065 & 28.8 & 10.832 \\
9 & 64.1084 & 94.3145 & 30.2061 & 3.074 & 28.8 & 10.868 \\
Criteria & $\geq 3.15$ & $\geq 4.87$ & $\geq 1.71$ & $\geq 0.2$ & $\geq 15$ & $\geq 0.15$ \\
Kondisi & Diterima & Diterima & Diterima & Diterima & Diterima & Diterima \\
\hline \hline
\end{tabular}

2) Pemeriksaan Kondisi Trim

Perhitungan trim dilakukan untuk mengetahui apakah kapal mengalami trim buritan atau trim haluan, dimana kondisi kapal akan berubah secara otomatis akibat perubahan kondisi pemuatan. Pemeriksaan trim ini mengacu pada SOLAS Reg. II/7, dimana kondisi trim maksimum yang diperbolehkan adalah $0.5 \%$ Lwl. Karena pada software maxsurf stability tidak terjadi keolengan atau perubahan kondisi dari kapal pada setiap loadcase, maka dilakukan perhitungan secara manual menggunakan metode parsons pada situasi even keel.

Tabel 5.

Hasil Pemeriksaan Trim SPB Kim Heng

\begin{tabular}{rcc}
\hline \hline \multicolumn{2}{c}{ Trim Summary } \\
\hline No & Item & Result \\
1 & $\mathrm{~KB} / \mathrm{T}$ & 0.51 \\
2 & $\mathrm{~KB} / \mathrm{T}$ & 1.08 \\
3 & $\mathrm{C} 1$ & 0.07 \\
4 & $\mathrm{IT}$ & 13813.91 \\
5 & $\mathrm{BMT}$ & 9.40 \\
6 & $\mathrm{CIL}$ & 0.07 \\
7 & $\mathrm{IL}$ & 176102.73 \\
8 & $\mathrm{BML}$ & 119.86 \\
9 & $\mathrm{GML}$ & 116.77 \\
10 & Trim & 1.045 meter \\
\hline \hline
\end{tabular}

\section{G. Pembuatan General Arrangement dan 3D Modeling}

Rencana Umum berisi pengaturan peletakan ruangan, perlengkapan dan juga peralatan, serta pembagian sekat [7]. Gambar rencana umum dibuat menggunakan gambar rencana garis yang ada (data perusahaan), dengan mengambil bagian terluar dari rencana garis. Dalam proses pembuatan desain rencana umum SPB Kim Heng, sepenuhnya menggunakan software AutoCad 2010 dan diperoleh hasil seperti pada Gambar 5

Setelah pembuatan rencana umum, dilanjutkan dengan permodelan 3D, dengan memproyeksian sesuai dengan rencana umum. Pengerjaan permodelan 3D dibantu dengan dua software yaitu Maxsurf dan Sketchup 2016. 3D Model untuk kapal ini dapat dilihat pada Gambar 5. 


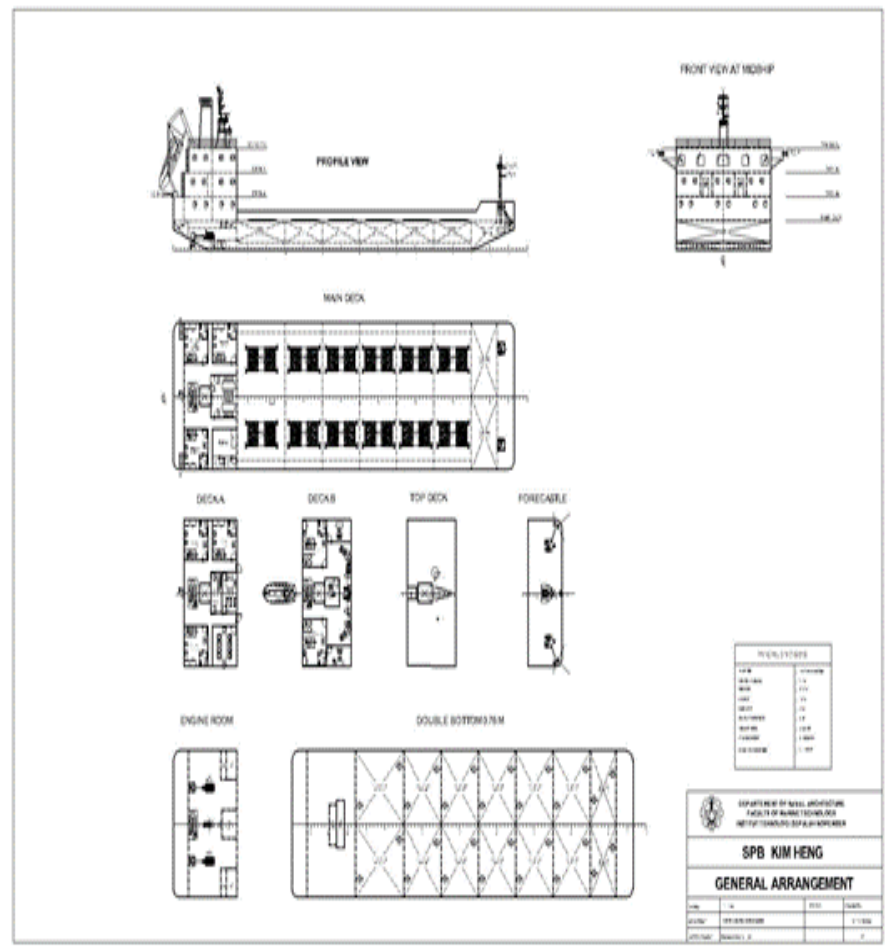

Gambar 4. General Arrangement SPB Kim Heng
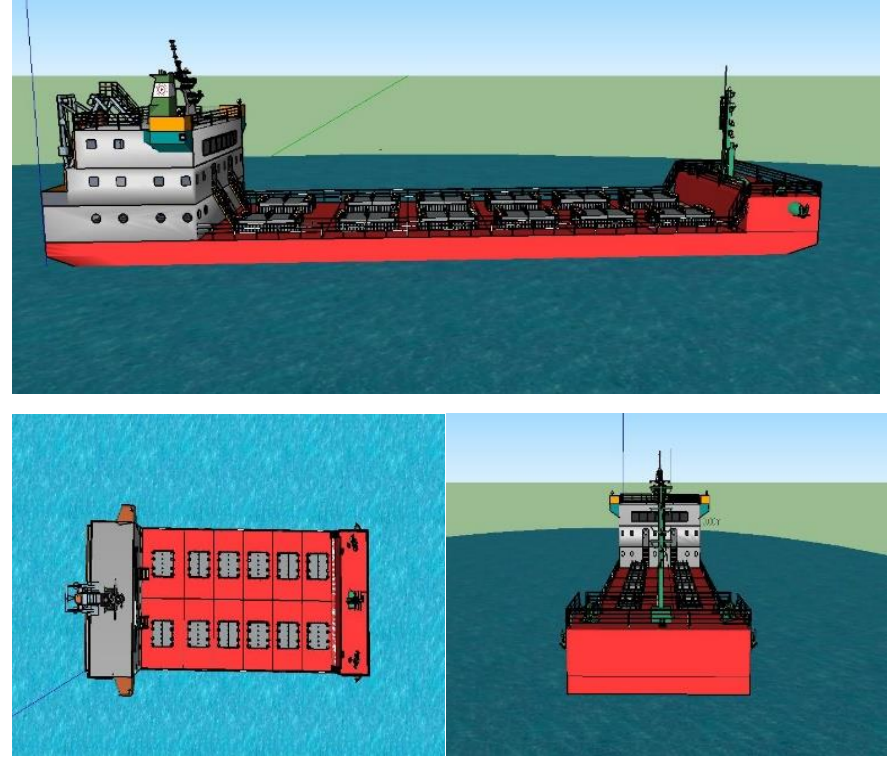

Gambar 5. 3D Model SPB Kim Heng

\section{ANALISIS EKONOMIS}

Analisis ekonomis yang dilakukan disini memeiliki beberapa tahap sebelum akhirnya dapat mengetahui kapan biaya pembangannan kapal ini mencapai Break Even Point(BEP). Yang pertama ialah menghitung biaya pembangunan kapal, dimana dalam hal ini termasuk biaya pembelian kapal/barge, biaya konversinya, dimana diperoleh biaya pembangunan sebesar Rp15,936,542,123, selanjutnya menghitung operation cost, dimana operation cost ini meliputi biaya cicilan pinjaman, Gaji crew, Biaya perawatan kapal, Asuransi, dan estimasi biaya perlengkapan kapal. Selanjutnya menghitung Biaya perjalanan kapal, yang meliputi biaya pembelian bahan bakar, fresh water, dan port charge.

Selanjutnya ialah menghitung biaya bongkar muat kapal, setelah semua biaya yang disebutkan diperoleh, nilanya keseluruhan biaya tersebut dijumlahkan yang nantinya akan dibagi dengan produksi ikan selama setahun untuk memperoleh biaya pengiriman ikan hidup, setelah biaya pengiriman diperoleh dilakukan perhitungan cash flow untuk mengetahui kapal semua investasi yang dikeluarkan dapat kembali, dan berdasarkan perhitunan diperoleh waktu 6 tahun untuk mencapai BEP.

\section{KESIMPULAN}

Setelah dilakukan analisis secara teknis dan ekonomis maka kesimpulan dari Studi berjudul Konversi Barge Batubara menjadi Kapal Pengangkut Ikan Hidup Untuk Perairan Sumbawa ini adalah sebagai berikut:

1. Berdasarkan data tangkapan dan potensi ikan diperairan Sumbawa diperoleh payload sebesar 856.23 ton. Untuk tujuan pengiriman awal yaitu Provinsi Bali dengan jarak tempuh 90.4 nautical miles. Dengan ukuran utama SPB :

- Loa : $54.9 \mathrm{~m}$

-B : $15.25 \mathrm{~m}$

$\bullet \mathrm{H}: 3.05 \mathrm{~m}$

- $\mathrm{T}: 2.1 \mathrm{~m}$

2. Melalui perhitungan teknis yang dilakukan diperoleh hasil untuk pemenuhan freeboard, untuk pemenuhan stabilitas dengan 9 loadcase mengacu kepada kriteria Intact Stability (IS) Code Reg. III/3.1.2., sudah memenuhi keselurah loadcase, dan pada trim yang mengacu pada SOLAS Reg. II/7 diperoleh trim buritan yang tidak melebihi 0.5\%xLpp kapal sebesar $0.2745 \mathrm{~m}$.

3. Dari perhitungan secara ekonomis dieroleh hasil sebagai berikut:

- Building Cost

- Operation Cost

- Loan from bank

- Loan Duration

- Discount Rate from bank

- Net Present Value (NPV)

- Internal Rate of Return (IRR) : $22 \%$
Payback Period 5 Tah

\section{UCAPAN TERIMA KASIH}

Penulis mengucapkan terima kasih kepada Bapak I Made Dwi Artha Giri selaku Manager PT. MITRATIRTA LOKALESTARI yang telah berkenan memberikan data barge Kim Heng.

\section{DAFTAR PUSTAKA}

D. Y. Akbar, "Analisis Teknis dan Ekonomis Konversi Deck Cargo Barge $250 \mathrm{ft}$ Menjadi Restobarge, untuk Perairan Gili TrawanganGili Meno, Lombok," 2016.

[2] D. Santoso, "Pengelolaan Perikanan Tangkap Berbasis Ikan Unggulan do Selat Alas Provinsi Nusa Tenggara Barat," 2015.

[3] E. . Rawson, K.J. and Tupper, Basic Ship Theory (5th ed., Vol. 1). Oxford: Butterworth-Heinemann, 2001.

[4] H. Mulya, "Analisis Teknis dan Ekonomis Pembangunan SelfPropelled Barge Batubara dari Sumatera Selatan untuk Menunjang Operasional PLTU Suralaya," 2006.

[5] IMO, International Convention on Load Lines. London: Lloyd's 
[6] IMO and I. Resolution, Intact Stability (IS) Code-Intact Stability for All Types of Ships. .

[7] R. A. Hutama, "Desain Self-Propelled Barge Resort untuk Wisata bahari di Perairan Lombok-Bali," 2016. 